\title{
A língua portuguesa no samba
}

\section{Portuguese for samba El protugués em El samba}

O presente texto revela como o gênero de música popular é resultado do ambiente sociocultural de origem. Já que a língua é uma marca cultura, é certo que a sua forma musical é decisivamente marcada pela língua na qual suas letras serão escritas. Assim, demonstra-se como o samba revela essa estreita relação com a língua.
This text shows how the genre of popular music is the result of the socio-cultural environment where it has born. Language is a culture brand so its musical expressions are marked by the language in which it will be written. It's demonstrated how close is the relationship between samba and the language.
Este texto revela como El género de la música popular es el resultado del ambiente socio-cultural que lo origina. Ya que la lengua es una marca de una cultura, es verdad que su forma musical es decisivamente marcada por el idioma en el cual se escribirán sus letras. De esa forma queda demostrado como el samba muestra esa estrecha relación con la lengua.
Palavras-chave: Língua, Samba, Português.

\section{Autor:}

\section{Zé Arnaldo Guima}

(José Arnaldo Guimarães Filho) é professor, compositor e poeta. Escreveu "Palavra sã", de poesias, lançado em 2001, e "Pequeno dicionário do futebolês", em 2014. Gravou e lançou os cds "Bem feito", 2000 e "Aviso à praça", em 2013. Prepara, para lançamento em breve, "A língua no Fundo de Quintal - A gíria na Linguagem do Samba", de onde foi tirado, em forma $d e$ resumo o artigo "a Língua portuguesa no samba" $e$ " $O$ assassinato da garota de Ipanema”, romance policial.

E-mail: zearnaldoguima@gmail.com

todo gênero de música popular é resultado do ambiente sociocultural em que se origina. ele é criado para ser o veículo de expressão artística de uma comunidade. Por isso, suas letras giram em torno de uma temática recorrente, de interesse e reconhecimento das pessoas que formam a matriz social em que se forjou, e a sua forma musical é decisivamente marcada pela língua na qual suas letras serão escritas.

O rock americano, por exemplo, é do jeito que é porque foi criado para dar voz aos anseios dos jovens das grandes cidades americanas, falantes, obviamente, do inglês, no fim da década de 1940. Ao ouvirmos uma composição nesse gênero, esperamos o acompanhamento típico de, pelo menos, guitarra, contrabaixo e bateria, a estrutura rítmico-melódico-harmônica que o caracteriza indubitavelmente e a prosódia anglofônica, para a qual ele foi criado e que o caracterizou enquanto formato musical. estranhamos uma canção nesse estilo cantada em outra língua porque percebemos as incongruências e os choques entre o formato musical que ele originalmente tem e a prosódia estranha à qual tem que se adaptar. É como enfiar um pé 42 num sapato 39. No Brasil nossos roqueiros sofrem criando letras, na nossa língua, que se adaptem a esse gênero musical. Nesse processo, buscam enxertar palavras com sons próximos aos do inglês e, por isso, abusam dos ditongos e das sílabas nasais. Se na letra, a tarefa não foi bem realizada, cabe ao cantor, na interpretação, adaptar os nossos vocábulos, pronunciando-os como se não fossem falantes nativos do português.

Assim também é com o baião, que tem suas características calcadas no dialeto nordestino e tematiza quase sempre a vida no campo, as agruras da seca, e a inexorabilidade da fuga para o sul-sudeste, a saudade de casa, as festas de São João, etc. A moderna música baiana é o reflexo da língua e do jeito de ser malemolente dos soteropolitanos assim como a guarânia sul-mato-grossense acompanha o som bilíngue da fronteira com o Paraguai.

O samba carioca nasceu na região denominada por Heitor dos Prazeres de Pequena África, que engloba a Zona Portuária e a Cidade Nova. Habitada por pessoas pobres, de maioria negra e de origem baiana, é resultado das intensas migrações internas e externas de que o Rio de Janeiro foi alvo após a Abolição. No início do século xx, essa população, que morava em casebres e cortiços, foi escorraçada de suas moradias pela Reforma da cidade e teve que se abrigar nos morros do centro, de modo a continuarem próximos das ocupações adjacentes ao cais do porto, ou se deslocar para os subúrbios mais distantes.

o samba logo se tornou a voz daquela gente que tinha nele e em seus criadores o canal através do qual externavam suas mazelas amorosas ou sociais, davam vazão às suas angústias, ou simplesmente registravam os percalços da vida, quase sempre de forma bem-humorada. Por ser oriundo de uma comunidade social de certa forma homogênea, os sambas refletem em suas letras, além dos temas que mais tocam seus criadores e adeptos, a fala de que se servem no dia a dia para a intercomunicação.

Esse "jeito especial de falar" que se construiu nessa comunidade é que caracteriza o novo gênero musical que surge e que lhe dá o sabor que tem até hoje.

A fala carioca, que é a forma pela qual aquela gente se apropria da língua portuguesa, determina o samba como gênero musical. 
A melodia e o rimo se moldam à fala dos que o criam e de quem o canta nas primeiras rodas. Ao lado da estrutura musical (ritmo, melodia e harmonia) que caracteriza todo gênero, do acompanhamento harmônico típico (violão, sete cordas e cavaquinho), dos instrumentos de percussão (que são inventados junto com ele), e da dança malemolente de seus adeptos, a linguagem do samba é uma de suas marcas e é, como as demais, determinante para a sua forma definitiva.

Aqui, cabe chamar a atenção para um aspecto. o samba foi por muito tempo relegado a um segundo plano pelos consumidores brancos, "por ser uma música de negros, indolentes e libidinosos". torcia-se o nariz para essa música que levou anos até ser aceita nos salões. muito do preconceito de que por muito tempo o samba foi vítima advém de sua linguagem, dentro do qual se ressaltam os usos não abonados pela norma padrão, a temática distanciada dos moradores "do asfalto" e o uso de gírias.

Nesse contexto, vale falar pela primeira vez da gíria, que é utilizada sem cerimônia nas letras dos primeiros sambas. o emprego das gírias reforça a oralidade que marca as letras do samba, não fossem assim as de qualquer canção, de qualquer gênero, em sua maioria. No samba, essa marca de oralidade é ainda mais presente e explícita porque muitas canções nascem de improviso, nos desafios do partido-alto, em que dois ou mais versadores duelam após o canto uníssono de um refrão que lhes serve de mote.

voltando à história. A população negra e mestiça que se desloca em primeiro lugar da zona portuária para os morros do Centro do Rio e, logo depois, para os subúrbios e favelas da Zona Norte, leva a língua que se forjara na Pequena África e a espalha pela cidade. junto com ela, vai o samba e tudo o que o cerca porque ele é, como percebeu Zé Kéti em samba metalinguístico e antológico, verdadeiramente a "voz do morro".

A língua dos morros e dos subúrbios mantém-se viva e, por isso, em constante evolução, mas de certa forma homogênea, pelos contatos que continua havendo entre seus moradores, parentes e ex-vizinhos, e pela extraordinária força centrípeta que esse gênero musical demonstra, sobretudo depois do surgimento das escolas de samba.

A fala mestiça carioca que surgira na Pequena África continua sendo comum aos habitantes das favelas pelas ligações culturais, sociais, religiosas e familiares que seus moradores perpetuam. O samba estará semprepresente nas festas e nas cerimônias religiosas, antes, durante e depois das celebrações. ele é o elemento comum às comunidades que surgem e crescem por toda a cidade, junto com as manifestações religiosas e culturais de menor retumbância.

Já consolidado, o samba se transformou e deu frutos diversos, variando-se e adaptando-se às mudanças e aos am-
Foto: http://escrevendoprapensar.blogspot.com.br

bientes em que era recebido. em cada escola, originária de uma favela, ganhou uma batida diferente e, conforme o dialeto da localidade, modificava-se, "dançando conforme a língua”. Noel rosa levou-o para os salões e para as rádios. Suas letras "falam" de outros temas e de outro jeito e através dele, o samba conquistou a classe média, até virar bossa-nova, em que assume um formato bem diferente do samba ancestral, porque a linguagem à qual estará cosido será outra.

No fim dos anos de 1970, no Bloco Carnavalesco Cacique de Ramos, após as peladas das noites de quarta-feira, reuniam-se jovens músicos para uma informal roda de samba que deveria ser, como aspiravam seus criadores, "como as de antigamente". Sem amplificação de som, como nos primórdios, mas com muito mais gente em volta. $\mathrm{O}$ repertório era formado por "sambas da antiga", que logo passam a conviver com canções recém-compostas porque muitos compositores inéditos ou esquecidos frequentam esses encontros musicais e ganham nele, democraticamente, espaço para divulgar suas obras.

Nas rodas do cacique, ao lado dos tradicionais pandeiro, surdo, violão e cavaquinho, ouvem-se novo sons que vêm dos tantãs, dos repiques de mão e do banjo com braço de cavaquinho, uma novidade levada para lá por Almir guineto, um dos integrantes originais do fundo de quintal. um novo formato de samba está sendo processado porque também uma nova linguagem, diferente daquela do limiar do século $\mathrm{xx}$, já anda nas bocas dos habitantes das agora chamadas comunidades. Os temas também se modificam e o samba, de novo, servil à sua gente, se acomoda aos novos tempos, e se transforma em pagode.

Rapidamente o pagode do Cacique de Ramos transforma-se numevento de sucesso. À quadra do bloco de embalo, acorrem os amantes febris do gênero, carentes desse tipo de reunião, que perdera espaço, nas escolas de samba e nos morros;nestes, por causa da violência e do encolhimento das religiões africanas, parceiras do samba desde sua gênese, naquelas porque já não havia, paradoxalmente, lugar, apesar do gigantismo das agremiações carnavalescas, para o "samba de meio de ano", engolido pela melhor performance comercial do samba enredo.

Vários cantores frequentam o Cacique em busca de novas "pérolas" para seu repertório. beth carvalho, grande madrinha do grupo, frequentadora habitual das rodas que ocorriam embaixo das "tamarineiras", convida os seus componentes para acompanhá-la em um de seus discos de maior sucesso, "pé no chão", de 1978. devido ao sucesso do disco de sua madrinha e divulgadora com a participação decisiva do grupo, a indústria fonográfica contrata os rapazes do Cacique de Ramos, antes amadores, para gravar um disco que, sugestivamente tem o nome de "Samba é no fundo de quintal". 
Nesse primeiro trabalho, a mesma diversidade de estilos que se ouvia nas rodas das quartas-feiras, fruto da democracia autoral que permitia a qualquer um cantar sua obra ao menos uma vez, migra para o disco que busca, ainda, reproduzir a sonoridade dos pagodes do cacique. o disco alcança vendagem expressiva para um artista iniciante. 23 compositoresescrevem as doze canções que compõem o disco e outra de suas marcas se faz presente: a linguagem que embala as letras apresenta pela primeira vez aos incautos a língua de uso nos morros e subúrbios do rio de janeiro, recheada de gírias e de "plebeísmos".

Por esse motivo, o grupo sofre o preconceito de que o samba foi vítima em suas origens. Seu estilo, o pagode, é considerado menor, e as suas canções de menor prestígio do que as dos baluartes do gênero, sobretudo Cartola, Ataulfo Alves e Nelson cavaquinho, cujas letras e músicas eram elogiadas até pelos intelectuais da zona sul do rio de janeiro.

o samba, após uma década de sucesso e de altas vendagens, perde espaço para o Rock Brasil nos anos de 1990 e,mais uma vez, se recolhe. Sua índole permanece, apesar das transformações, de certa forma previsíveis, que sofre desde a sua criação. As condições sociais e culturais em que foi forjado desaparecem paulatinamente e, por isso, desalojado de seus ambientes naturais, o terreiro e a quadra das agremiações carnavalescas, ele busca pousos diferentes, até ressurgir, mais uma vez, desta vez em novo pouso, a Lapa, onde foi recebido com reverência e reprocessado por novos músicos e intérpretes.

A língua em que suas letras são escritas também se adapta aos novos tempos. os novo criadores - Arlindo cruz, Sombrinha, Zeca pagodinho, Trio Calafrio, Toninho Gerais, Serginho Meriti - fiéis às raízes de onde descendem, escrevem seus poemas musicais na mesmalíngua em que namoram, rezam, brigam ou fazem suas compras. As gírias e as construções típicas da linguagem popular e oral desses novos tempos, estão à mostra, com todas as letras, à disposição de quem queira estuda-las para compreendê-las, porque o samba, além de todas as suas riquezas, oferta-nos generosamente mais essa dádiva: a de ser um registro notável e original de nossa "inculta e bela" língua portuguesa. 